Acta vet. scand. $1974,15,439-441$.

Brief Communication

\author{
PASTEURELLA HAEMOLYTICA \\ ASSOCIATED WITH PNEUMONIA IN A FOAL
}

\title{
A CASE REPORT
}

Although pasteurellosis, and particularly Pasteurella multocida infection, is widespread among a great variety of animal species (Merchant \& Packer 1967), pasteurellosis is rare among horses. Without indicating the Pasteurella species isolated, Kolomakin (1960) and Dan'shev (1960) in Russia, and Golat (1961) in Poland reported acute pasteurellosis among horses. Valdes Ornelas (1963) described an epizootic among horses in Mexico where Pasteurella haemolytica type 1 was isolated. Pavri \& Apte (1967) described outbreaks of P. multocida among horses and donkeys in India. A case of septicaemia in a foal with pneumonia as the most salient feature and from which P. haemolytica was isolated in mixed infection, is described in the following.

The foal was healthy at the time of normal parturition but soon showed severe dyspnoe and died four days later.

At necropsy, the carcass showed moderate icterus. In the lungs dark-red areas of firm consistency were widely distributed and the cut surface was dark and somewhat dry. The myocardium showed a pale colour. There were no macroscopic changes in the kidneys. Histologically, haematoxylin-eosin stained sections of the lungs revealed a prominent fibrinous pneumonia with scattered miliary necroses infiltrated with neutrophils. Gram-stained sections revealed an abundance of Gram-positive cocci in the necroses, but moderate numbers in other parts of the lung tissue. In some areas accumulations of Gram-negative bipolar organisms were seen. The liver showed acute congestion and focal necroses with moderate cellular reaction.

Bacteriological examination of the lungs resulted in moderate growth of Actinobacillus equuli but abundant growth of Streptococcus zooepidemicus, and of an organism which satisfied the main criteria according to Breed et al. (1957) and proved to be 
Pasteurella haemolytica. Biochemically, the strain isolated differed from the standard criteria by fermenting mannose and salicin but not inositol, mannitol or sorbitol. Furthermore, it was urease positive, a property it shared with some strains isolated from the human respiratory tract (Henriksen \& Jyssum 1961). The strain was characterized by its distinct pathogenicity to mice. Bacteriological examination of the liver and spleen resulted in pure culture of $\mathrm{A}$. equuli.

The isolation of $\mathrm{A}$. equuli in pure culture from the liver and spleen, and in mixed infection from the lungs, strongly indicates that the foal died of septicaemia due to this organism. Apart from the lungs, the slight macroscopic changes revealed that the course of the disease was unusually acute, an observation which is consistent with the description of infection with A. equuli (Jubb \& Kennedy 1970). As to the three organisms isolated from the lungs, any of them alone could cause a severe and fatal pneumonia. It is known that Str. zooepidemicus may inhabit the respiratory tract of horses as a potential pathogen (Merchant \& Packer). However, it is unknown whether P. haemolytica may play a similar role, or even function as a primary invader, in pneumonia of horses. The abundance with which this organism occurred, together with its pathogenicity to mice, which is a rather unusual property (Merchant \& Packer), indicates that the organism was partly responsible for the pneumonia in the case described here. In conclusion, the prevalence of P. haemolytica in horses and its role as a primary or secondary invader in respiratory diseases need to be investigated further.

\section{F. Saxegaard}

The Department of Microbiology and Immunology, and

R. Svenkerud

The Department of Pathology,

Veterinary College of Norway, Oslo, Norway.

\section{REFERENCES}

Breed, R. S., E. G. O. Murray \& N. R. Smith: Bergey's Manual of Determinative Bacteriology. The Williams and Wilkins Co., Baltimore 1957.

Dan'shev, I. A.: Pasteurellosis in horses. Veterinariya 1960, 37, No. 7, 47-48. Original available but not translated; abstracted in Vet. Bull. (Weybridge) 196.0, 30, 67.0. 
Golat, T.: Dwa przypadki pasterelozy u koni. (Pasteurella infection in two horses). Med. weteryn. 1961, 17, 25-26. Original available but not translated; abstracted in Vet. Bull. (Weybridge) $1961,31,508$.

Henriksen, S. D. \& K. Jyssum: A new variety of Pasteurella haemolytica from the human respiratory tract. Acta path. microbiol. scand. 1961, 50, 443.

Kolomakin, G. A.: Pasteurellosis in foals. Veterinariya 1960, 37, No. 7, 46-47. Original available but not translated; abstracted in Vet. Bull. (Weybridge) 1960, 30, 670.

Merchant, I. A. \& R. A. Packer: Veterinary Bacteriology and Virology. The Iowa State University Press, Ames, Iowa 1967.

Jubb, K. V. F. \& P. C. Kennedy: Pathology of Domestic Animals. Acad. Press, New York and London 1970.

Pavri, K. M. \& V. H. Apte: Isolation of Pasteurella multocida from a fatal disease of horses and donkeys in India. Vet. Rec. 1967, $80,437-439$.

Valdes Ornelas, O.: La Pasteurelosis de los equiedos en México. (Equine pasteurellosis in Mexico). Bull. Off. int. Epiz. 1963, 60, 1059-1062. Original available but not translated; abstracted in Vet. Bull. (Weybridge) 1964, 34, 447.

(Received June 10, 1974).

Reprints may be requested from: F. Saxegaard, The Department of Microbiology and Immunology, Veterinary College of Norway, Postbox 8146, Oslo Dep., Oslo 1, Norway. 